\title{
Assessing the genetic diversity of Dioscorea alata and related species from Colombia through inter-simple sequence repeat (ISSR) markers
}

\author{
Christian C. Castañeda-Cardona ${ }^{1 *}$, Yacenia Morillo-Coronado ${ }^{2}$, and Ana C. Morillo ${ }^{3}$ \\ ${ }^{1}$ Universidad de los Llanos, Facultad de Ciencias Agropecuarias, km 12 Vía a Puerto López, Vda. Barcelona, Villavicencio, \\ Meta, Colombia. "Corresponding author (christian.castaneda@unillanos.edu.co). \\ ${ }^{2}$ Corporación Colombiana de Investigación Agropecuaria-Agrosavia, Centro de Investigación Palmira, Diagonal a la intersección de la \\ Carrera 36A con Calle 23, Palmira, Valle del Cauca, Colombia. \\ ${ }^{3}$ Universidad Pedagógica y Tecnológica de Colombia, Facultad de Ciencias Agropecuarias, Avenida Central del Norte 39-115, \\ Tunja, Boyacá, Colombia.
}

Received: 20 May 2020; Accepted: 28 July 2020; doi:10.4067/S0718-58392020000400608

\section{ABSTRACT}

Dioscorea, commonly known as yam, is an economically, socially, and culturally-relevant tuber crop in many tropical countries. This study aimed to characterize the genetic diversity of Dioscorea alata L. and related species from Colombia ( 42 D. alata L., 6 D. bulbifera L., 3 D. rotundata Poir., and 3 D. trifida L. f.) through seven intersimple sequence repeat (ISSR) markers. The plant material was collected in five departments of Colombia. The seven ISSR generated 164 bands that showed high polymorphism (83.62\%). Nei-Li genetic diversity coefficient (0.66) and Shannon information index (0.2636) revealed a high level of genetic diversity. The 54 genotypes were grouped into six groups according to geographic location but not by species. We found moderate genetic differentiation $\left(\mathrm{G}_{s t}=0.13\right)$ and high gene flow $\left(\mathrm{N}_{\mathrm{m}}=2.7367\right)$. The analysis of molecular variance (AMOVA) showed higher variation (86\%) within groups than among groups (14\%). Our results suggest that the high genetic diversity in yam in Colombia can be exploited in future work on crop improvement.

Key words: Molecular markers, ploidy, population structure, yam.

\section{INTRODUCTION}

Yam (Dioscorea spp.) is the fourth most economically important tuber crop worldwide, after potato (Solanum tuberosum L.), cassava (Manihot esculenta Crantz), and sweet potato (Ipomoea batatas [L.] Poir.) (Dansi et al., 2013). This crop comprises a basic food source for over 300 million people in Tropical and sub-Tropical regions of Africa, Asia, South America, and the Caribbean (Ngo-Ngwe et al., 2014). In 2018, the global yam production was 73.0 million tons. Of this total production, Nigeria produced 47.9 million tons $(65.7 \%)$ in a crop area of 5.9 million hectares, which represented $70 \%$ of the global planted area (8.6 million hectares) (FAO, 2018). There are more than 600 species of Dioscorea, but only 10 of them are cultivated species of economic importance (Oben et al., 2016). These are Dioscorea alata L. (known as water yam, winged yam or great yam), D. esculenta (Lour.) Burkill (lesser yam or Chinese yam), D. batatas Decne. or $D$. opposita Thunb. originating from Asia, D. bulbifera L. (air potato yam), D. cayenensis Lam.-D. rotundata Poir. complex, D. dumetorum (Kunth) Pax (bitter yam or trifoliate yam) originating from Africa, D. trifida L. f. originating from America, D. nummularia Lam. and D. pentaphylla L. originating from both Asia and Oceania (Girma et al., 2012).

In Colombia, yam is grown in 18 out of 32 departments, among which Bolívar, Córdoba, and Sucre comprise 38\%, 34\%, and $15 \%$ of the national planted area, followed by Antioquia and Choco with $4.3 \%$ and 2.3\%, respectively. In 2018, for Colombia, there was a crop planted area of 38.941 ha with a yield of $9.48 \mathrm{t} \mathrm{ha}^{-1}$ and a production of $453.298 \mathrm{t}$ (MADR, 2019). 
Assessing the genetic diversity of a plant species using molecular DNA markers is an important tool for cultivar identification, taxonomic and phylogenetic studies, genetic mapping, and germplasm management and conservation (Onda and Mochida, 2016). The genetic diversity of yam has been characterized using several markers, including RFLP (Mukherjee and Bhat, 2013), SSR (Arnau et al., 2017; Mulualem et al., 2018), AFLP (Rivera-Jiménez et al., 2011; Wendawek et al., 2013), ISSR (Kung et al., 2016; Ousmael et al., 2019), and SNP (Agre et al., 2019). Bhattacharjee et al. (2018) constructed a genetic linkage map for D. alata based on 380 EST-SSR markers. Furthermore, Cormier et al. (2019) generated the first high-density genetic map for D. alata based on sequence-based genotyping, which provided new knowledge on sex determination in yam.

Inter simple sequence repeat (ISSR)-PCR is a simple and rapid technique that combines the advantages of SSR and AFLP with the universality of RAPD markers (Henareh et al., 2016). ISSR markers were developed to explore microsatellite repetitions without the need for DNA sequencing (Zietkiewicz et al., 1994). This genetic marker relies on PCR amplification of DNA segments between adjacent and inversely oriented microsatellites. The primers target microsatellites with a length of 16 to 25 bp and are composed of two, three, four or five nucleotides. ISSR markers are very stable, dominant, multiallelic, reproducible, and generate a high number of polymorphic fragments (Martínez et al., 2020). This study aimed to characterize the genetic variability of 54 Dioscorea spp. genotypes from different regions of Colombia using ISSR molecular markers to contribute to better planning for yam germplasm conservation and genetic improvement strategies.

\section{MATERIALS AND METHODS}

\section{Plant material}

We collected 54 genotypes of yam (Dioscorea spp.) from different localities in five departments of Colombia, including four genotypes from Córdoba, seven from the Municipality of Medina (Cundinamarca), 15 from Putumayo, two from Yopal (Casanare), 17 from Restrepo (Meta), and nine from Villavicencio (Meta). The identification of the genotypes in the field was carried out taking into account the classification given by farmers and researchers in the area, based on morphological characters of the tuber, architecture (number and color of stems, spinescence) and morphology of aerial organs (shape, size, texture and leaf color) that defines some of the characteristics of the genus and species, as well as the key to the main Dioscorea species provided by IPGRI/IITA (1997). Taking into account the above, the 54 genotypes were grouped into four taxonomic groups namely D. alata L., D. trifida L. f., D. bulbifera L., and D. rotundata Poir. (Table 1). We randomly selected two to three fresh young leaves per genotype, which were stored in sealed bags with silica gel for subsequent DNA extraction.

\section{DNA extraction and ISSR-PCR conditions}

DNA extraction was performed at the Plant Biotechnology laboratory of Universidad de los Llanos, Municipality of Villavicencio (Meta) $\left(4^{\circ} 4^{\prime} 30^{\prime} \mathrm{N}, 7^{\circ} 35^{\prime} 7^{\prime} \mathrm{W} ; 467 \mathrm{~m}\right.$ a.s.1.) We followed the DNA isolation protocol described by Dellaporta et al. (1983): 50-100 mg leaf tissue were taken, macerated with liquid nitrogen and placed in an eppendorf tube. To each tube $800 \mu \mathrm{L}$ hot $\left(65^{\circ} \mathrm{C}\right)$ plant extraction buffer (PEB) (1 M Tris-HCl, pH 8.0, 0.5 M EDTA, pH 8.0, $5 \mathrm{M}$ $\mathrm{NaCl}$ and $55 \mu \mathrm{L} 20 \%$ SDS) were added. One percent $\beta$-mercaptoethanol was added to the pre-warm PEB just before use. A parallel extraction, $1 \%$ polyvinylpyrrolidone (PVP) was added. The tubes were capped and inverted gently 6-7 times to mix the sample with the buffer. The solution was incubated at $65^{\circ} \mathrm{C}$ in water bath for 20 min occasional mixing to homogenize the samples. After, it was removed and uncapped. The tubes were allowed to cool at room temperature for $2 \mathrm{~min} ; 250 \mu \mathrm{L} 5 \mathrm{M}$ ice-cold potassium acetate was added and recapped, mixed and incubated on ice-cold for $20 \mathrm{~min}$. It was then span at $12000 \mathrm{rpm}$ for $10 \mathrm{~min}$ and supernatant was transferred into new tube. Ice-cold isopropanol $(640 \mu \mathrm{L})$ was added, gently mixed and stored in a freezer $\left(-20^{\circ} \mathrm{C}\right)$ for $2 \mathrm{~h}$ to precipitate the DNA. After this time, the samples were centrifuged at $12000 \mathrm{rpm}$ for $10 \mathrm{~min}$. The isopropanol was carefully discarded; tube was drained on clean paper towel for $1 \mathrm{~h}$. The DNA pellet was washed twice in $100 \mu \mathrm{L}$ cold $70 \%$ ethanol for $20 \mathrm{~min}$, and then the tubes were placed on a paper towels to allow the pellet to dry completely. The pellet was resuspended in $100 \mu \mathrm{L} 1 \mathrm{X}$ TE buffer, followed by $2 \mu \mathrm{L}$ of 10 ng $\mu \mathrm{L}^{-1} \mathrm{RNase}$. The final incubation of the solution was done for $40 \mathrm{~min}$ at $37^{\circ} \mathrm{C}$ with gentle mixing at 10 min intervals. The DNA was stored in $-20^{\circ} \mathrm{C}$. 
Table 1. Genotypes of Dioscorea spp. used for molecular characterization with ISSR markers.

\begin{tabular}{|c|c|c|c|c|c|}
\hline ID & Origin & Species & ID & Origin & Species \\
\hline 1 & Restrepo & D. bulbifera & 28 & Putumayo & D. alata \\
\hline 2 & Restrepo & D. alata & 29 & Putumayo & D. alata \\
\hline 3 & Villavicencio & D. bulbifera & 30 & Putumayo & D. alata \\
\hline 4 & Putumayo & D. alata & 31 & Putumayo & D. alata \\
\hline 5 & Restrepo & D. alata & 32 & Putumayo & D. alata \\
\hline 6 & Putumayo & D. alata & 33 & Putumayo & D. alata \\
\hline 7 & Villavicencio & D. alata & 34 & Putumayo & D. alata \\
\hline 8 & Restrepo & D. trifida & 35 & Putumayo & D. alata \\
\hline 9 & Restrepo & D. alata & 36 & Putumayo & D. alata \\
\hline 10 & Restrepo & D. alata & 37 & Putumayo & D. alata \\
\hline 11 & Restrepo & D. trifida & 38 & Putumayo & D. alata \\
\hline 12 & Restrepo & D. alata & 39 & Putumayo & D. alata \\
\hline 13 & Restrepo & D. alata & 40 & Restrepo & D. alata \\
\hline 14 & Yopal & D. alata & 41 & Restrepo & D. trifida \\
\hline 15 & Yopal & D. alata & 42 & Restrepo & D. alata \\
\hline 16 & Villavicencio & D. bulbifera & 43 & Restrepo & D. alata \\
\hline 17 & Villavicencio & D. bulbifera & 44 & Restrepo & D. alata \\
\hline 18 & Villavicencio & D. bulbifera & 45 & Restrepo & D. alata \\
\hline 19 & Villavicencio & D. bulbifera & 46 & Restrepo & D. alata \\
\hline 20 & Villavicencio & D. alata & 47 & Restrepo & D. alata \\
\hline 21 & Villavicencio & D. alata & 48 & Medina & D. alata \\
\hline 22 & Villavicencio & D. alata & 49 & Medina & D. alata \\
\hline 23 & Córdoba & D. rotundata & 50 & Medina & D. alata \\
\hline 24 & Córdoba & D. rotundata & 51 & Medina & D. alata \\
\hline 25 & Córdoba & D. rotundata & 52 & Medina & D. alata \\
\hline 26 & Córdoba & D. alata & 53 & Medina & D. alata \\
\hline 27 & Putumayo & D. alata & 54 & Medina & D. alata \\
\hline
\end{tabular}

We assessed DNA quality and quantity through $0.8 \%$ agarose gel electrophoresis using TBE $0.5 \mathrm{X}(0.045 \mathrm{M}$ Tris-borate; $0.001 \mathrm{M}$ EDTA) running buffer at $80 \mathrm{~V}$ during $45 \mathrm{~min}$, then visualized the DNA with GelRed stain (Biotium, Fremont, California, USA) on a benchtop UV transilluminator M-15 (UVP LLC, Upland, California, USA). We quantified the DNA samples by comparing to lambda DNA concentration standards, and diluted the DNA in $100 \mu \mathrm{L}$ HPLC-grade water to a final concentration of $10 \mathrm{ng} \mu \mathrm{L}^{-1}$.

PCR amplification was performed with seven ISSR primers (Table 2). The PCR reaction contained $10 \mathrm{ng}$ genomic DNA, $0.2 \mathrm{mM}$ dNTPs, $1.5 \mathrm{mM} \mathrm{MgCl} 2,2.0 \mu \mathrm{M}$ of each primer, $1 \mathrm{X}$ PCR buffer, and $1 \mathrm{U}$ Taq polymerase (Bioline, London, UK) in a final volume of $25 \mu \mathrm{L}$. The PCR amplification was run on a TCA0001 thermocycler (Thermo Fisher Scientific, Vantaa, Finland). The PCR conditions were initial denaturation at $95^{\circ} \mathrm{C}$ for $5 \mathrm{~min}$; followed by 37 cycles of denaturation at $95{ }^{\circ} \mathrm{C}$ for $30 \mathrm{~s}$, annealing at $50-58{ }^{\circ} \mathrm{C}$ for $45 \mathrm{~s}$ (depending on the primer used; Table 2), extension at $72{ }^{\circ} \mathrm{C}$ for $2 \mathrm{~min}$; and a final extension at $72{ }^{\circ} \mathrm{C}$ for $7 \mathrm{~min}$. We included a negative control or blank without DNA to confirm the absence of contamination. The amplicons were loaded onto $1.2 \%$ agarose gels run at $100 \mathrm{~V}$ for $1 \mathrm{~h}$ and $20 \mathrm{~min}$, stained with GelRed, and visualized on a benchtop UV transilluminator M-15.

Table 2. ISSR primers used to determine the genetic diversity of Dioscorea spp.

\begin{tabular}{lcc}
\hline Primer & Sequence (5' a 3') & $\begin{array}{c}\text { Hybridization } \\
\text { temperature }\end{array}$ \\
\hline CCA & DDB(CCA)5 & 55 \\
CGA & DHB(CGA)5 & 58 \\
AG & HBH(AG)7A & 50 \\
CT & DYD(CT)7C & 55 \\
TG & HVH(TG)7T & 55 \\
CA & DBDA(CA)7 & 50 \\
ACA & BDB(ACA)5 & 50 \\
\hline
\end{tabular}

Single-letter abbreviations for multiple base positions: $\mathrm{H}:(\mathrm{A}, \mathrm{C}, \mathrm{T})$; B: $(\mathrm{C}$, G, T); V: (A, C, G); D: (A, G, T); Y (C, T). 


\section{Data analysis}

Amplified products were scored as present (1) or absent (0) to construct a binary matrix. Genetic similarity (GS) was estimated for all genotype pairs using the equation (Nei and $\mathrm{Li}, 1979)$ :

$$
G S_{i j}=2 N_{i j} /\left(2 N_{i j}+N_{i}+N_{j}\right)
$$

where $G S_{i j}$ represents the similarity estimate between the genotypes i and $\mathrm{j}$, based on the ISSR data, $N_{i j}$ is the total number of bands common to $\mathrm{i}$ and $\mathrm{j}$, and $N_{i}$ and $N_{j}$ correspond to the number of bands found in genotypes $\mathrm{i}$ and $\mathrm{j}$. The matrix generated with the GS estimates was used to cluster the genotypes in a dendrogram obtained by the unweighted pair group with arithmetic mean (UPGMA) using Numerical Taxonomy System for Personal Computer NTSYS statistical package (version 2.02 PC, Setauket, New York, USA). Cophenetic correlation coefficient between similarity matrix and dendrogram cophenetic values was estimated to validate the dendrogram in relation to the original similarity estimates and the binary data matrix analyzed using COPH and MXCOMP programs in NTSYS-pc.

The statistical package POPGENE version 3.2 (Yeh et al., 1999) was used to estimate the Nei's genetic diversity (H), Shannon information index (I), coefficient of genetic differentiation $\left(\mathrm{G}_{s t}\right)$, number and percentage of polymorphic loci, and gene flow $\left(\mathrm{N}_{\mathrm{m}}\right)$ using the formula $N_{m}=0.5\left(1-G_{s t}\right) / G_{s t}($ McDermott and McDonald, 1993).

We performed a Bayesian analysis using STRUCTURE statistical package version 2.3.1 (Pritchard et al., 2000) to determine the population structure of the genotypes using an admixture model, correlated allelic frequencies, and 10 iterations for each K (number of clusters assumed) with a burning of 100000 interactions, followed by 200000 Monte Carlo Markov Chains (MCMC). We selected the most probable number of clusters using $\Delta \mathrm{k}$ method (Evanno et al., 2005). Finally, an analysis of molecular variance (AMOVA) was computed using Arlequin version 3.5 (Excoffier and Lischer, 2010) to identify the proportion of variation among and within the groups established according to the population structure analysis.

\section{RESULTS AND DISCUSSION}

\section{Genetic diversity}

The genetic characterization of 54 yam genotypes using seven ISSR primers yielded a total of 164 bands with an average of 23.43 bands for each primer. The fragment lengths ranged from 120 to $1500 \mathrm{bp}$. Among the total bands, 135 (82.3\%) were polymorphic, showing on average 19 bands for each ISSR primer (Table 3). The highest (34) and lowest (15) number of bands were generated by primers AG and CCA, CA, respectively. In the Figure 1 the amplification pattern generated by the CGA primer is displayed.

The high level of polymorphism $(83.62 \%)$ found here demonstrated a relatively high genetic diversity among genotypes of Dioscorea spp. Similarly, Kung et al. (2016) reported $90.2 \%$ of polymorphic loci for 99 accessions of D. japonica based on ISSR markers amplified through 15 primers. Wu et al. (2014) assessed the genetic diversity of 21 yam cultivars, including D. opposita, D. alata, D. persimilis Prain \& Burkill, and D. fordii Prain \& Burkill, from seven cultivated populations, finding a high level of polymorphism (95.3\%) based on 11 ISSR primers.

Nei's genetic diversity or expected heterozygosity $(\mathrm{H})$ and Shannon information index (I) were on average 0.66 and 0.2636 , respectively. These findings revealed high genetic diversity for the genotypes. Yam is a dioecious plant species that maintains high levels of heterozygosity, despite that it is propagated asexually through tuber sections or using the entire tuber. This level of heterozygosity could be mainly associated with the breeding system and self-incompatibility in yam (Ngailo et al., 2016), as well as the inclusion of genotypes from different localities, with the Department of Putumayo and the Municipality of Restrepo (Meta) presenting the highest values of heterozygosity of 0.71 and 0.63 , respectively. These values are due to the fact that the largest number of yam genotypes were collected in these localities. This shows the urgent need to increase the number of sampling sites in order to have the greatest genetic diversity of species of the genus Dioscorea. As expected, Yopal and Córdoba showed the lowest He values of 0.0534 and 0.2905, respectively. Finally, several factors, such as the geographic origin of the genotypes, climatic factors, dispersion patterns, life cycle, breeding system, and genetic composition, among others, significantly affect the genetic diversity of a species.

Nascimento et al. (2013) report that the high level of diversity found in 53 accessions of $D$. trifida with SSR and ISSR markers is directly related to the polyploid nature of this species and that it is reproduced through sexual and asexual propagation; therefore, individuals are usually heterozygote and preserve the allelic diversity at the individual level. 
Table 3. Number of loci, number and percentage of polymorphic loci, Nei's genetic diversity coefficient (H), coefficient of genetic differentiation $\left(G_{\mathrm{st}}\right)$, Shannon information index (I) for seven ISSR primers assessed in 54 Dioscorea spp. genotypes.

\begin{tabular}{lcccccc}
\hline Primer & Nr Loci & $\begin{array}{r}\text { Nr polymorphic } \\
\text { loci }\end{array}$ & $\begin{array}{r}\text { \% polymorphic } \\
\text { loci }\end{array}$ & H & $\mathrm{G}_{\text {st }}$ & $\mathrm{I}$ \\
\hline CT & 29 & 17 & 95.88 & 0.935 & 0.17 & \\
AG & 34 & 9 & 72.83 & 0.579 & 0.07 & \\
TG & 25 & 8 & 89.19 & 0.662 & 0.13 & \\
CCA & 15 & 9 & 90.48 & 0.682 & 0.14 & \\
CA & 15 & 11 & 84.33 & 0.561 & 0.07 & \\
ACA & 23 & 15 & 87.10 & 0.789 & 0.06 & \\
CGA & 23 & 13 & 65.52 & 0.433 & 0.24 & \\
Total & 164 & 82 & 83.62 & 0.660 & 0.13 & 0.2636 \\
\hline
\end{tabular}

Figure 1. Band patterns generated by the primer ISSR (CGA)n.

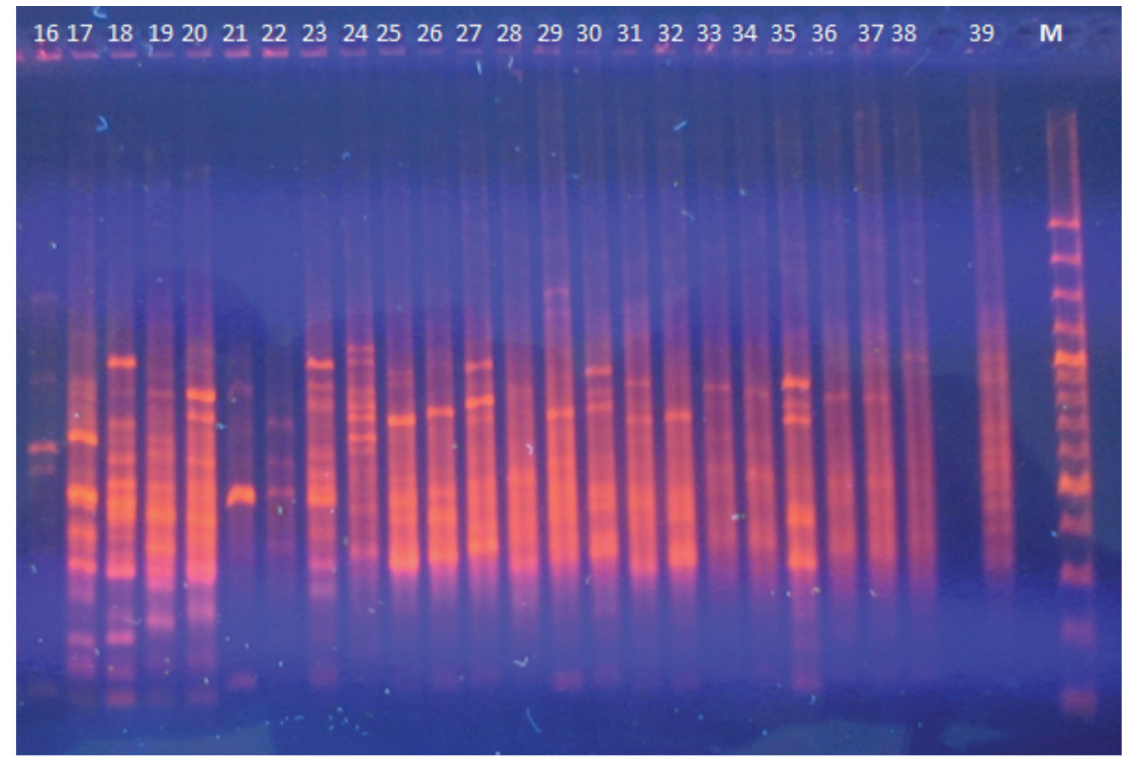

M: Molecular marker.

Our results agree with Ousmael et al. (2019), who assessed the genetic diversity of 77 accessions of Dioscorea spp. using six ISSR primers, finding high genetic diversity at the genus level with Shannon index of 0.36 and 0.53 , respectively. Siqueira et al. (2012) studied the genetic diversity of 36 commercial cultivars of D. alata using nine SSR markers, finding highly polymorphic loci (PIC $=0.57-0.77$ ), a high genetic diversity coefficient of 0.69 , and a Shannon-Wiener index of 1.29. Finally, high levels of genetic diversity using ISSR markers were also reported by Nascimento et al. (2013) and Kung et al. (2016). Other studies using SSR (Otoo et al., 2015; Arnau et al., 2017; Mulualem et al., 2018) and AFLP markers (Rivera-Jiménez et al., 2011) also reported high genetic diversity in yam.

We found an average value of $\mathrm{G}_{\mathrm{st}}$ (genetic differentiation coefficient) of 0.13 with a standard deviation of 0.04 , indicating moderate genetic differentiation. The CGA primer accounted for the largest variation with a $\mathrm{G}_{\mathrm{st}}$ of 0.24 , demonstrating that it is useful to differentiate among genotypes of Dioscorea. The value of $\mathrm{N}_{\mathrm{m}}=2.7367$ found here indicates high gene flow which is possibly due to seed dispersal mechanisms, pollen movement and individuals, among others (GelmiCandusso et al., 2017). Additionally, the allogamic nature of the species promotes constant gene flow among genotypes; consequently, there are no crossability barriers or high differentiation among the populations. 


\section{Clustering analysis}

The UPGMA analysis clustered the 54 genotypes into six groups (A, B, C, D, E, F) at a similarity level of 0.32 (Figure 2). The distinct groups were also supported by a high cophenetic correlation coefficient $(\mathrm{r}=0.97)$.

Group A comprised 18 genotypes, including 13 from the Department of Putumayo (6, 27, 28, 29, 30, 31, 32, 33, 34, 35, 36, 37, and 38), one from Cordoba (26), three from Restrepo (Meta) (1, 8, and 9), and one from Villavicencio (Meta) (3). Most genotypes in this group belong to the species $D$. alata (15), while the remaining three genotypes belong to $D$. bulbifera and D. trifida. Group B, with nine genotypes, clusters the majority of genotypes of D. bulbifera (4/6), as well as four genotypes of D. alata and one of D. trifida. Seven genotypes in group B we collected in the Department of Meta, namely Restrepo (11,12, and 13) and Villavicencio (16, 17, 18, and 19), and two genotypes were from the Department of Yopal (14 and 15). Group C contained 17 genotypes, including 16 belonging to $D$. alata and one to $D$. trifida. Seven genotypes $(49,50,51,52,53,54$, and 55) in this group were collected from the Llanos foothills of Medina (Cundinamarca), nine (2, 40, 41, 43, 44, 45, 46, 47, and 48) were from Restrepo (Meta), and one genotype was from Putumayo (39).

On the other hand, group D only contained genotypes of D. alata $(4,5$, and 7$)$ from the Departments of Putumayo, Restrepo, and Villavicencio, respectively. Group E included three genotypes of D. rotundata (23, 24, and 25) collected from the Department of Cordoba, as well as three genotypes of D. alata (20,21, and 22) from Villavicencio (Meta). Lastly, group F comprised a single genotype belonging to D. alata (10) that show a similarity coefficient of 0.26 and was the least related to the other genotypes. This genotype could be evaluated for its phenotypic performance and to be considered in Dioscorea breeding initiatives. Overall, our results demonstrate that ISSR markers can discriminate genotypes of yam according to their geographic origin, but not by species. It has been mentioned that the taxonomic complexity is typical of the genus Dioscorea due to an important morphological diversity. Hence, there is confusion in the name, identification and classification of yam species.

Figure 2. Dendrogram showing relationships among 54 genotypes of Dioscorea spp., according to the UPGMA analysis using seven ISSR markers.

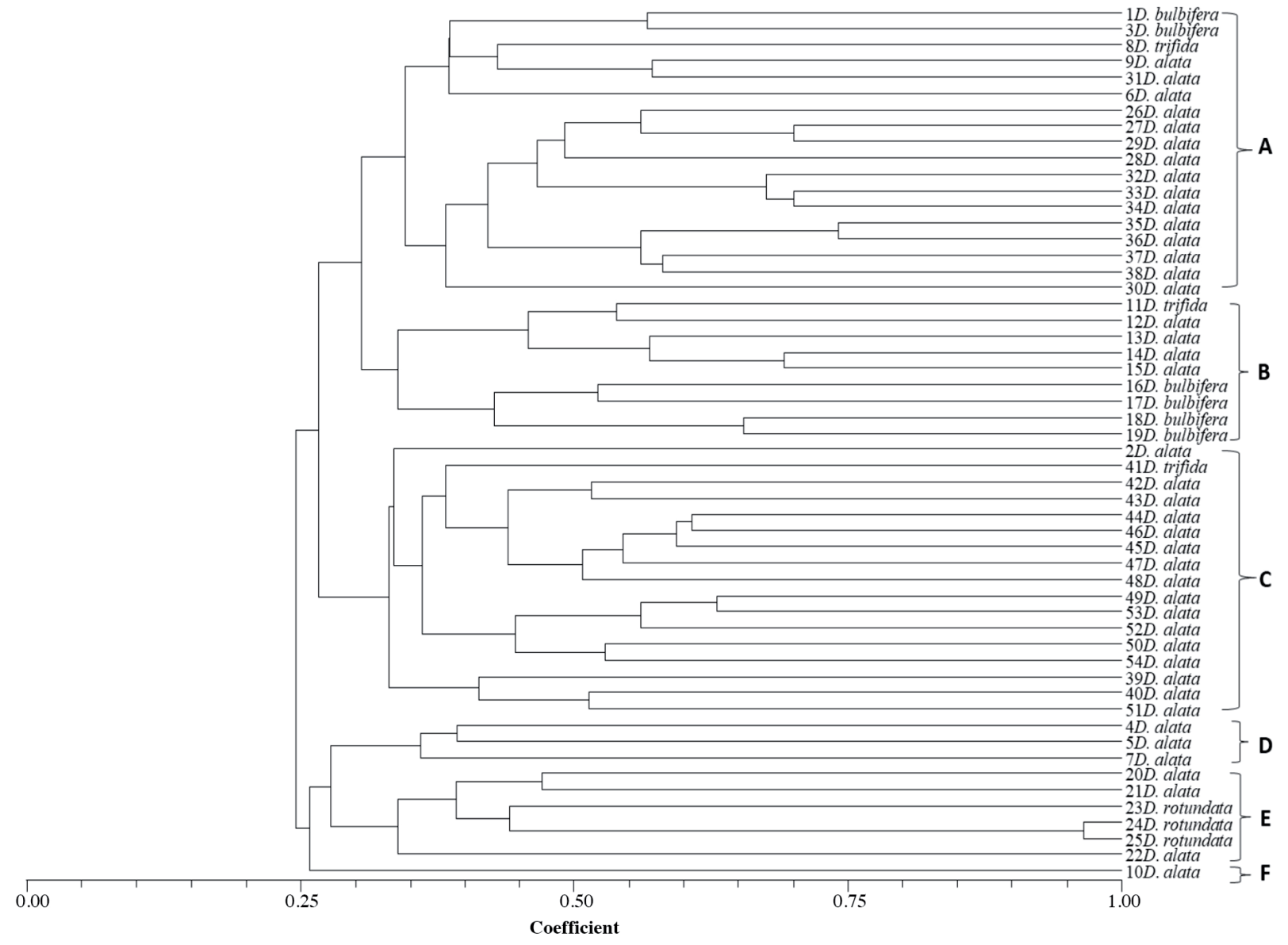




\section{Bayesian analysis of population structure}

We analyzed the population structure of 54 genotypes of yam based on a Bayesian model approached implemented using STRUCTURE v2.3.1. The Evanno method showed a $\Delta \mathrm{k}$ peak at $\mathrm{K}=3$, indicating that the genotypes are partitioned into three genetic groups, designated here as G1, G2, and G3 (Figure 3).

Forty-nine genotypes $(90.74 \%)$ were assigned to the three groups; particularly, the majority of genotypes were assigned to group G1 (22/49), while groups G2 and G3 contained 13 and 14 genotypes, respectively. The remaining five genotypes $(9.26 \%)$ that were not assigned to any group were derived from admixture between groups. We assigned an individual to a given population based on a probability threshold of $70 \%$. We found similar results between the population structure and clustering analyses since the distribution of the genotypes for both was based on geographic origin but there was no clear classification of genotypes according to the species to which they belong, as the formation of four clearly distinguished genetic groups was to be expected. Such groupings are possibly due to natural interspecific hybrids among the species evaluated, which are not supported in this study and no reports of hybridization processes among Colombian yam germplasm were found. In contrast, Rivera et al. (2011) in the assessment of intra and interspecific genetic diversity of yam (Dioscorea spp.) from the Colombian Caribbean region by AFLP markers, reported high genetic variability among the accessions studied giving as a result four genetic groups: D. alata L., D. rotundata Poir., D. esculenta (Lour.) Burkill and D. trifida L.f., which confirmed a correspondence between the morphological and molecular characterization and botanical classification. This awakens a great interest in continuing other research work in which a greater number of genotypes of the species D. rotundata, D. bulbifera and D. trifida should be included, as well as the use of molecular markers of codominant type, which allow clarifying the evolution and taxonomy of yams grown in traditional cultivation systems.

For instance, genetic group G1 was the most heterogeneous since it contained all of the four species and representative genotypes from five departments, mainly genotypes belonging to D. alata (12). This population also grouped six genotypes of $D$. bulbifera, three of $D$. rotundata, and one genotype of D. trifida. The He value for species D. alata was high, corresponding to 0.76 , with respect to the other species evaluated and a percentage of polymorphic loci of 94.96 . Several authors have found a wide genetic variation of genotypes of the species D. alata, with different molecular markers (Siqueira et al., 2012; Otoo et al., 2015), variation that can be attributed to different levels of ploidy, its allogamous nature, as well as a great variation in their morphological characteristics. Conversely, groups G2 and G3 are dominated by genotypes of the species D. alata. We found 12 genotypes from the Department of Putumayo and 1 from Córdoba in group G2, while group G3 grouped 6 genotypes from Medina and 8 from Restrepo.

Figure 3. Genetic structure of 54 genotypes of Dioscorea spp. according to K= 3, based on seven ISSR markers.

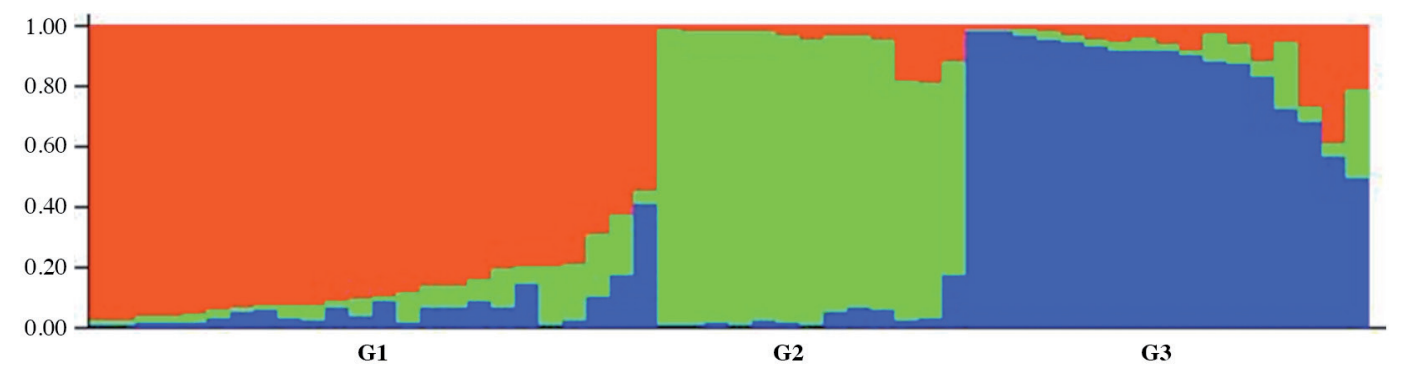

Table 4. Analysis of molecular variance (AMOVA) among and within populations using seven ISSR markers.

\begin{tabular}{lrcccc}
\hline Source of variation & df & $\begin{array}{c}\text { Sum of } \\
\text { squares }\end{array}$ & $\begin{array}{c}\text { Variance } \\
\text { components }\end{array}$ & $\begin{array}{c}\text { Total } \\
\text { variation }\end{array}$ & P-value* \\
\hline Among groups & 5 & 192.245 & 2.610 & $\%$ & 14 \\
Within groups & 48 & 800.810 & 16.684 & 86 & 0.001 \\
Total & 53 & 993.056 & 19.293 & & 0.001 \\
\hline
\end{tabular}

df: Degree of freedom. *Significance tests after 1000 permutations. 
The STRUCTURE analysis did not reveal genetic structure in the study population, as indicated by the genotype distribution of the different taxonomic groups. The genotypes were predominantly grouped into group G1, showing close genetic relationships between species. These results are consistent with a $\mathrm{G}_{\mathrm{st}}$ of 0.13 that indicates moderate genetic differentiation. Our findings demonstrate high gene flow between individuals possibly due to processes of seed dispersal, gamete movement, spontaneous hybridization and introgression, among others.

The analysis of molecular variance (AMOVA) showed that $86 \%$ of the variation was due to differences within groups, while $14 \%$ was attributed to differences among groups (Table 4). Similarly, Ousmael et al. (2019) found a higher proportion of variation within species (63.9\%) than among species (36.1\%) using ISSR markers to study the genetic diversity of yam (Dioscorea spp.) Moreover, Loko et al. (2016) found 96\% variation within populations and only 4\% among populations using 41 microsatellite markers to study the genetic diversity and relationships between 64 local varieties of yam. The high variation within populations could be due mainly to evolutionary dynamics and/or admixture in the field possibly facilitated by pollen flow (Ousmael et al., 2019). Our results demonstrate that the genetic diversity of a yam germplasm bank can be efficiently enriched when wild type genotypes are collected in one region and a low number of rare or diverse genotypes from other regions are later incorporated.

\section{CONCLUSIONS}

Our results demonstrate that ISSR markers are useful and powerful to assess the genetic relationships, polymorphism, and genetic diversity of yam cultivars. The high genetic diversity found represents a valuable source of genes and provides relevant information to identify promising parentals for genetic recombination programs. Finally, this information can also be used by producers to implement ex situ conservation strategies for autochthonous cultivars.

\section{REFERENCES}

Agre, P., Asibe, F., Darkwa, K., Edemodu, A., Bauchet, G., Asiedu, R., et al. 2019. Phenotypic and molecular assessment of genetic structure and diversity in a panel of winged yam (Dioscorea alata) clones and cultivars. Scientific Reports 9:18221. doi:10.1038/s41598-019-54761-3.

Arnau, G., Bhattacharjee, R., Chair,H., Malapa, R., Lebot, V., Abraham, K., et al. 2017. Understanding the genetic diversity and population structure of yam (Dioscorea alata L.) using microsatellite markers. PLOS ONE 12(3):e0174150. doi:10.1371/journal.pone.0174150.

Bhattacharjee, R., Nwadili, C.O., Saski, C.A., Agre, P., Scheffler, B.E., Augusto, J., et al. 2018. An EST-SSR based genetic linkage map and identification of QTLs for anthracnose disease resistance in water yam (Dioscorea alata L.) PLOS ONE 13(10):e0197717. doi:10.1371/journal.pone.0197717.

Cormier, F., Lawac, F., Maledon, E., Gravillon, M., Nudol, E., Mournet, P., et al. 2019. A reference high-density genetic map of greater yam (Dioscorea alata L.) Theoretical and Applied Genetics 132:1733-1744. doi:10.1007/s00122-019-03311-6.

Dansi, A., Dantsey-Barry, H., Dossou-Aminon, E.K.I., N'kpenu, E.K., Agré, A.P., Sunu, Y.D., et al. 2013. Varietal diversity and genetic erosion of cultivated yams (Dioscorea cayenensis Poir-D. rotundata Lam complex and D. alata L.) in Togo. International Journal of Biodiversity and Conservation 5:223-239. doi:10.5897/IJBC12.131.

Dellaporta, S.L., Wood, J., and Hicks, J.B. 1983. A plant DNA minipreparation: Version II. Plant Molecular Biology Reporter 1(4):19-21.

Evanno, G., Regnaut, S., and Goudet, J. 2005. Detecting the number of clusters of individuals using the software structure: A simulation study. Molecular Ecology 14:2611-2620.

Excoffier, L., and Lischer, H.E.L. 2010. Arlequin suite ver 3.5: A new series of programs to perform population genetics analyses under Linux and Windows. Molecular Ecology Resources 10(3):564-567.

FAO. 2018. FAOSTAT Statistical Division of the FAO of the United Nations, Rome, Italy. www.faostat.org. (accessed 8 April 2020).

Gelmi-Candusso, T.A., Heymann, E.W., and Heer, K. 2017. Effects of zoochory on the spatial genetic structure of plant populations. Molecular Ecology 26:5896-5910.

Girma, G., Korie, S., Dumet, D., and Franco, J. 2012. Improvement of accession distinctiveness as an added value to the global worth of the yam (Dioscorea spp.) genebank. International Journal of Conservation Science 3(3):199-206.

Henareh, M., Dursun, A., Abdollahi-Mandoulakani, B., and Haliloğlu, K. 2016. Assessment of genetic diversity in tomato landraces using ISSR markers. Genetika 48:25-35.

IPGRI/IITA. 1997. Descriptores para el ñame (Dioscorea spp.) International Institute of Tropical Agriculture (IITA), Ibadan, Nigeria/International Plant Genetic Resources Institute (IPGRI), Roma, Italia. 
Kung, T., Lin, K., and Lin, S. 2016. Genetic diversity of Dioscorea japonica germplasm in Taiwan revealed by inter-simple sequence repeat DNA markers. Plant Genetic Resources 14(3):211-218. doi:10.1017/S147926211500026X.

Loko, Y.L., Bhattacharjee, R., Agre, A.P., Dossou-Aminon, I., Orobiyi, A., Djedatin, G.L., et al. 2016. Genetic diversity and relationship of Guinea yam (Dioscorea cayenensis Lam.-D. rotundata Poir. complex) germplasm in Benin (West Africa) using microsatellite markers. Genetic Resources and Crop Evolution 64:1205-1219. doi:10.1007/s10722-016-0430-z.

MADR. 2019. El Ministerio de Agricultura lanzará este jueves la cadena productiva del ñame. Ministerio de Agricultura y Desarrollo Rural (MADR) de Colombia, Bogotá, Colombia. Editorial La República, Bogotá, Colombia. Available at https:// www.larepublica.co/economia/el-ministerio-de-agricultura-lanzara-este-jueves-la-cadena-productiva-del-name-2923671 (accessed 8 April 2020).

Martínez,M.A.,Morillo,A.C., and Reyes-Ardila,W.2020.Characterization of the genetic diversity in Passiflora spp.in the Boyacá Department, Colombia. Chilean Journal of Agricultural Research 80:342-351. doi:10.4067/S0718-58392020000300342.

McDermott, J.M., and McDonald, B.A. 1993. Gene flow in plant pathosystems. Annual Review of Phytopathology 31:353-373. doi:10.1146/annurev.py.31.090193.002033.

Mukherjee, P., and Bhat, K.V. 2013. Phylogenetic relationship of wild and cultivated yam species (Dioscorea spp.) of India inferred from PCR-RFLP analysis of two cpDNA loci. Plant Systematics and Evolution 299:1587-1597.

Mulualem, T., Mekbib, F., Shimelis, H., Gebre, E., and Amelework, B. 2018. Genetic diversity of yam (Dioscorea spp.) landrace collections from Ethiopia using simple sequence repeat markers. Australian Journal of Crop Science 12(8):12231230. doi:10.21475/ajcs.18.12.08.PNE885.

Nascimento, W.F., Rodrigues, J.F., Koehler, S., Gepts, P., and Veasey, E.A. 2013. Spatially structured genetic diversity of the Amerindian yam (Dioscorea trifida L.) assessed by SSR and ISSR markers in Southern Brazil. Genetic Resources and Crop Evolution 60:2405-2420. doi:10.1007/s10722-013-0008-y.

Nei, M., and Li, W.H. 1979. Mathematical model for studying genetic variation in terms of restriction endonucleases. Proceedings of the National Academy of Sciences of the United States of America 76:5269-5273. doi:10.1073/pnas.76.10.5269.

Ngailo, S., Shimelis, H., Sibiya, J., Amelework, B., and Mtunda, K. 2016. Genetic diversity assessment of Tanzanian sweet potato genotypes using simple sequence repeat markers. South African Journal of Botany 102:40-45. doi:10.1016/j.sajb.2015.08.001.

Ngo-Ngwe, M.F.S., Joly, S., Bourge, M., Brown, S., and Omokolo, D.N. 2014. Nuclear DNA content analysis of four cultivated species of yams (Dioscorea spp.) from Cameroon. Journal of Plant Breeding and Genetic 02(02):87-95.

Oben, J.A., Egbe, A.E., Chuyong, G.B., and Tabot, P.T. 2016. Diversity of yam (Dioscorea spp.) populations in Southwestern Region of Cameroon. American Journal of Life Sciences 4(6):187-194.

Onda, Y., and Mochida, K. 2016. Exploring genetic diversity in plants using high-throughput sequencing techniques. Current Genomics 17:358-367. doi:10.2174/1389202917666160331202742.

Otoo, E., Anokye, M., Asare, P.A., and Tetteh, J.P. 2015. Molecular categorization of some water yam (Dioscorea alata L.) germplasm in Ghana using microsatellite (SSR) markers. Journal of Agricultural Science 7(10):225.

Ousmael, K.M., Tesfaye, K., and Hailesilassie, T. 2019. Genetic diversity assessment of yams (Dioscorea spp.) from Ethiopia using inter simple sequence repeat (ISSR) markers. African Journal of Biotechnology 18(30):970-977. doi:10.5897/AJB2018.16446.

Pritchard, J.K., Stephens, M., and Donnelly, P. 2000. Inference of population structure using multilocus genotype data. Genetics 155:945-949.

Rivera-Jiménez, H.J., Álvarez-Soto, A., Palacio-Mejía, J.D., Barrios-Leal, D.Y., y López-Álvarez, D. 2011. Diversidad genética intra e inter-específica de ñame (Dioscorea spp.) de la región Caribe de Colombia mediante marcadores AFLP. Acta Agronómica 60(4):328-338.

Siqueira, M.V.B.M., Dequi-Giovanni, G., Corazon-Guivin, M.A., Feltran, J.C., and Veasey, E.A. 2012. DNA fingerprinting of water yam (Dioscorea alata) cultivars in Brazil based on microsatellite markers. Horticultura Brasileira 30(4):653-659. doi:10.1590/S0102-05362012000400015.

Wendawek, A., Sebsebe, D., Fay, M.F., Smith, R.J., Nordal, I., and Wilkin, P. 2013. Genetic diversity and species delimitation in the cultivated and wild Guinea yams (Dioscorea spp.) from Southwest Ethiopia as determined by AFLP (amplified fragment length polymorphism) markers. Genetic Resources and Crop Evolution 60:1365-1375. doi:10.1007/s10722-012-9925-4.

Wu, Z., Li, X., Lin, X., Jiang, W., Tao, Z., Mantri, N., et al. 2014. Genetic diversity analysis of yams (Dioscorea spp.) cultivated in China using ISSR and SRAP markers. Genetic Resources and Crop Evolution 61(3):639-650. doi:10.1007/s10722-013-0065-2.

Yeh, F.C, Yang, R.C., Boyle, T.B.J., Ye,Z.H., and Mao, J.X. 1999. POPGENE version 1.31 Microsoft Window-based freeware for population genetic analysis: Quick user guide. University of Alberta, Edmonton, Canada.

Zietkiewicz, E., Rafalski, A., and Labuda, D. 1994. Genome fingerprinting by simple sequence repeat (SSR) anchored polymerase chain reaction amplification. Genome 20:176-83. 